Article

\title{
Fucoidan-Manganese Dioxide Nanoparticles Potentiate Radiation Therapy by Co-Targeting Tumor Hypoxia and Angiogenesis
}

\author{
Sung-Won Shin ${ }^{1,2}$, Wooju Jung ${ }^{3}$, Changhoon Choi ${ }^{1}$, Shin-Yeong Kim ${ }^{1}$, Arang Son ${ }^{1}$, \\ Hakyoung Kim ${ }^{1}$, Nohyun Lee ${ }^{3, *}$ and Hee Chul Park ${ }^{1,2, *}$ \\ 1 Department of Radiation Oncology, Samsung Medical Center, Seoul 06351, Korea; \\ camuserik@gmail.com (S.-W.S.); chchoi93@gmail.com (C.C.); syeong.kim@sbri.co.kr (S.-Y.K.); \\ arang.son@sbri.co.kr (A.S.); khk614@gmail.com (H.K.) \\ 2 School of Medicine, Sungkyunkwan University, Seoul 06351, Korea \\ 3 School of Advanced Materials Engineering, Kookmin University, Seoul 02707, Korea; jwj139@daum.net \\ * Correspondence: nohyunlee@kookmin.ac.kr (N.L.); hee.ro.park@gmail.com (H.C.P.); \\ Tel.: +82-2-910-4227 (N.L.); +82-2-3410-2605 (H.C.P.)
}

Received: 20 November 2018; Accepted: 13 December 2018; Published: 15 December 2018

\begin{abstract}
Tumor hypoxia is a major mechanism of resistance to radiation therapy (RT), which is associated with poor prognosis in affected cancer patients. Various approaches to treat hypoxic and radioresistant cancers, including pancreatic cancer, have shown limited success. Fucoidan, a polysaccharide from brown seaweed, has antitumor and antiangiogenesis activities. Here, we discuss the development of fucoidan-coated manganese dioxide nanoparticles (Fuco- $\mathrm{MnO}_{2}$-NPs) and testing of the therapeutic potential with RT using pancreatic cancer models. In vitro data showed that Fuco- $\mathrm{MnO}_{2}$-NPs generated oxygen efficiently in the presence of $\mathrm{H}_{2} \mathrm{O}_{2}$ and substantially suppressed HIF-1 expression under a hypoxic condition in human pancreatic cancer cells. Fuco- $\mathrm{MnO}_{2}-\mathrm{NPs}$ reversed hypoxia-induced radioresistance by decreasing clonogenic survival and increasing DNA damage and apoptotic cell death in response to RT. In a BxPC3 xenograft mouse model, the combination treatment with Fuco- $\mathrm{MnO}_{2}-\mathrm{NPs}$ and RT resulted in a greater tumor growth delay than RT alone. Fucoidan-coated NPs, but not naked ones, further suppressed tumor angiogenesis, as judged by immunohistochemistry data with diminished expression of phosphorylated vascular endothelial growth factor receptor 2 (VEGFR2) and CD31. These data suggest that Fuco- $\mathrm{MnO}_{2}-\mathrm{NPs}$ may potentiate the effects of RT via dual targeting of tumor hypoxia and angiogenesis, and they are of great clinical potential in the treatment of hypoxic, radioresistant pancreatic cancer.
\end{abstract}

Keywords: tumor hypoxia; radiation therapy; nanoparticles; fucoidan

\section{Introduction}

Pancreatic cancer is the fourth most common cause of cancer-related deaths and was estimated to be responsible for 43,090 deaths in the United States in 2017 [1,2]. The most common type, pancreatic adenocarcinoma, typically has a very poor prognosis. Following diagnosis, $25 \%$ of people survive for one year and $5 \%$ live for five years. For cancers diagnosed early, the five-year survival rate rises to about $20 \%$ [3]. Surgical removal of the tumor is the only cure for this cancer. Whether or not surgical resection can be offered depends on the cancer spread and the proximity of the major blood vessels to the pancreas. Unfortunately, surgical resection is only possible in approximately $20 \%$ of new cases. Chemotherapy or chemoradiotherapy is likely to be offered to most patients with advanced pancreatic cancer. However, the changes made in the last few years have only increased survival times by a few months [4], and the high rate of treatment failure remains a challenge [5]. 
Radiation therapy (RT) may constitute a part of the treatment to shrink tumors to a resectable state, but its use on unresectable tumors remains controversial due to conflicting results from previous studies [6]. Regarding radiation physics, recent advances in radiation delivery techniques, such as intensity-modulated radiotherapy and image-guided radiotherapy, have contributed to the preservation of normal tissue, which enables a decrease in normal tissue toxicity while increasing local control rate through safe dose-escalation [7]. In terms of radiation biology, oxygen is an important factor in determining the radiosensitivity of tumor cells. The presence or absence of oxygen dramatically influences the biologic effects of X-rays. Oxygen can enhance and fix radiation damage such as DNA double-strand breaks (DSBs), causing cancer cells to undergo apoptosis $[8,9]$. In the absence of oxygen, damage produced by the indirect action may be repaired. In addition, the importance of rapid and complete reoxygenation is well-known because hypoxic cells have little influence on the outcome of a fractionated radiation schedule. In addition, oxygen can also regulate radiosensitivity by altering intracellular gene expression. Tumor hypoxia leads to the activation of a transcription factor, called hypoxia-inducible-factor-1 (HIF-1). HIF- $1 \alpha$ is involved in resistance to radiotherapy, chemotherapy and metastasis through the regulation of cell death, DNA damage repair, cell proliferation, and angiogenesis $[10,11]$. Therefore, in hypoxic tumors, the therapeutic efficacy of radiotherapy is decreased.

To date, various strategies such as hyperbaric oxygen therapy and drugs that preferentially kill or sensitize hypoxic cells to radiation [12] have been proposed to overcome hypoxia-induced radiation resistance. Unfortunately, side effects, such as increased reactive oxygen species (ROS) generation and off-target toxicity, limit clinical applications. Multifunctional nanoplatforms are attracting increasing attention in this regard. Albumin-coated manganese dioxide nanoparticles $\left(\mathrm{A}-\mathrm{MnO}_{2}-\mathrm{NPs}\right)$ were developed to overcome tumor hypoxia; they can generate oxygen through decomposition of endogenous hydrogen peroxide $\left(\mathrm{H}_{2} \mathrm{O}_{2}\right)$ and increase $\mathrm{pH}$. Modulation of the tumor microenvironment by A- $\mathrm{MnO}_{2}-\mathrm{NPs}$ can enhance the RT response [13]. Further development of $\mathrm{MnO}_{2}-\mathrm{NPs}$ has been performed for tuning oxygen generation rates and optimizing colloidal stability under physiological conditions, which has resulted in the marked potentiation of RT in murine tumor models [14]. $\mathrm{MnO}_{2}$-NPs conjugated with acriflavine, a potent HIF-1 inhibitor, were also recently developed and shown to enhance RT response and abscopal effects, suggesting the great potential of $\mathrm{MnO}_{2}$-based nanoplatforms as radiation sensitizers for treating metastatic as well as primary tumors [15].

Seaweeds are rich in biologically active polysaccharides that exhibit a broad spectrum of biological activities. Fucoidan is a fucose-rich, sulfated cell-wall polysaccharide isolated from brown seaweed. Fucoidan has diverse activities, including anticancer and anticoagulant activities [16]. Recent studies have suggested that fucoidan can act as an anticancer agent through the modulation of the immune system $[17,18]$. Fucoidan induces the maturation of dendritic cells and, in association with other cytokines, shapes the immune responses that are mediated by T-cells. Fucoidan also has an inhibitory role on cancer metastasis and angiogenesis via the downregulation of matrix-metalloproteinase 2 and the vascular endothelial growth factor (VEGF) [19]. In this study, we newly designed fucoidan-manganese dioxide nanoparticles (Fuco- $\mathrm{MnO}_{2}-\mathrm{NPs}$ ) with dual functionality by conjugation with bioactive fucoidan and oxygen-generating $\mathrm{MnO}_{2}$-NPs. Subsequently, we investigated the preclinical potential of the use of a Fuco- $\mathrm{MnO}_{2}-\mathrm{NP}$ formulation in a pancreatic cancer model. The aim was to meet the urgent need for novel hypoxic tumor radiosensitizers.

\section{Results}

\subsection{Synthesis of Fuco-MnO $\mathrm{O}_{2}-\mathrm{NPS}$}

Fuco- $\mathrm{MnO}_{2}-\mathrm{NPs}$ were synthesized according to a previous report, with slight modifications [13]. Manganese permanganate $\left(\mathrm{KMnO}_{4}\right)$ was reduced in the presence of poly (allylamine hydrochloride) $(\mathrm{PAH})$ at room temperature, resulting in stable $\mathrm{MnO}_{2}-\mathrm{NPs}$. Figure 1a shows a transmission electron 
microscopy (TEM) image of $\mathrm{MnO}_{2}$-NPs. Owing to the small core size and low crystallinity, the morphology of $\mathrm{MnO}_{2}$-NPs was not clearly revealed. However, ultraviolet-visible (UV-Vis) spectra showed the disappearance of $\mathrm{KMnO}_{4}$ peaks around $315 \mathrm{~nm}$ and $530 \mathrm{~nm}$ and the appearance of a broad peak around $300 \mathrm{~nm}$, representing the surface plasmon band of colloidal $\mathrm{MnO}_{2}$ (Figure 1b). The hydrodynamic size and zeta-potential measurements of PAH-coated NPs revealed an over $17 \mathrm{~nm}$ in overall size and $+55.1 \mathrm{mV}$ in surface charge (Figure 1c,d). Since a strong positive surface charge may induce cytotoxicity, the surfaces of the nanoparticles were modified with negative fucoidan using electrostatic interaction. After fucoidan absorption, the overall size and surface charge of Fuco- $\mathrm{MnO}_{2}-\mathrm{NPs}$ were changed to $-48.61 \mathrm{~nm}$ and $-24.6 \mathrm{mV}$, respectively (Figure 1c,d). No severe aggregation was observed after fucoidan coating.
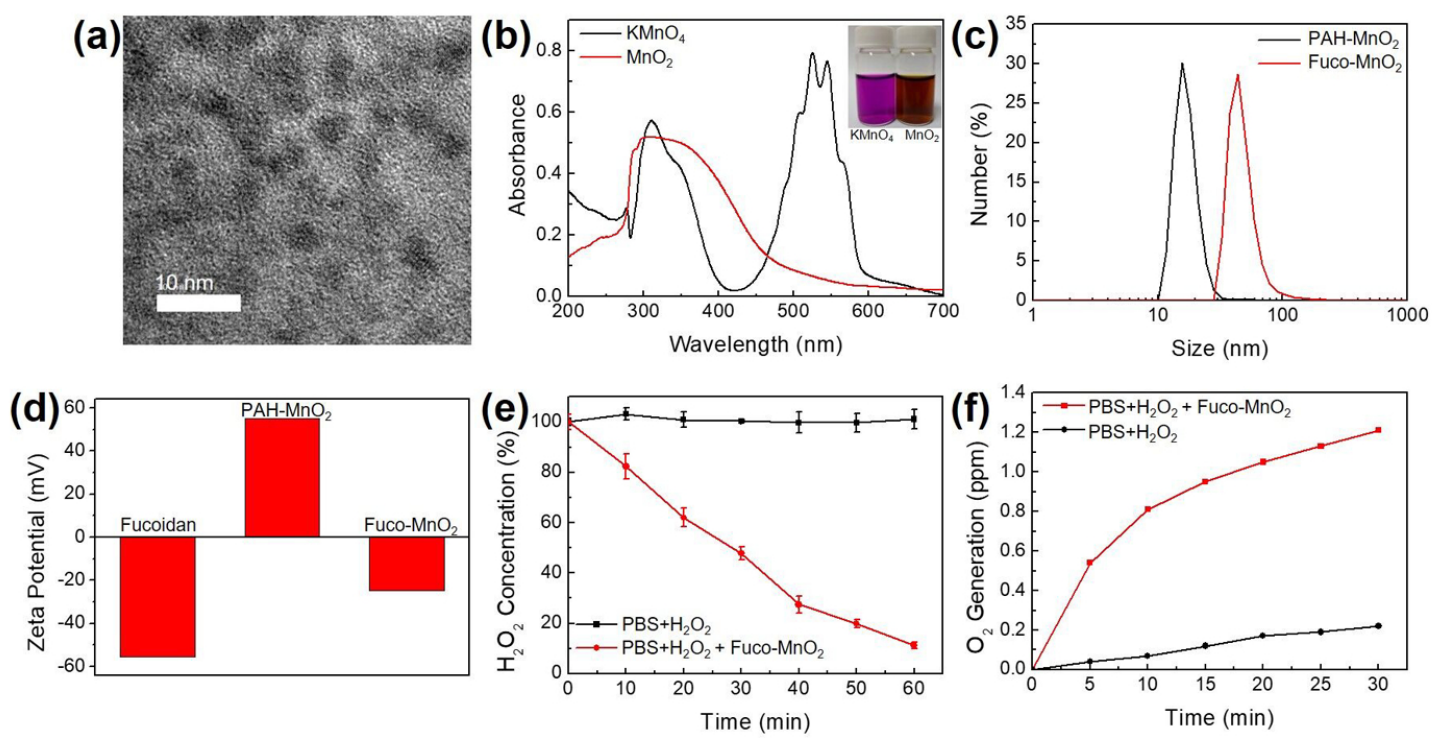

Figure 1. Synthesis of fucoidan-coated manganese dioxide nanoparticles (Fuco- $\mathrm{MnO}_{2}-\mathrm{NPs}$ ) and their reactivity toward endogenous hydrogen peroxide $\left(\mathrm{H}_{2} \mathrm{O}_{2}\right)$. (a) Transmission electron microscopy (TEM) image of $\mathrm{MnO}_{2}$-NPs. (b) Ultraviolet-visible (UV-Vis) absorption spectra of $\mathrm{KMnO}_{4}$ solution and $\mathrm{MnO}_{2}$-NPs. A broad peak at approximately $300 \mathrm{~nm}$ indicated the formation of $\mathrm{MnO}_{2}-\mathrm{NPs}$. (c) Hydrodynamic size distribution of $\mathrm{MnO}_{2}-\mathrm{NPs}$ before and after fucoidan coating. (d) Effect of fucoidan coating on zeta-potential of $\mathrm{MnO}_{2}$-NPs. (e) Decomposition of $\mathrm{H}_{2} \mathrm{O}_{2}$ by Fuco- $\mathrm{MnO}_{2}-\mathrm{NPs}$ $(n=3)$. (f) Generation of oxygen after treatment with Fuco-MnO $\mathrm{M}_{2}-\mathrm{NPs}$.

The reactivity of the Fuco- $\mathrm{MnO}_{2}$-NPs was evaluated using time-dependent $\mathrm{H}_{2} \mathrm{O}_{2}$ assays after the addition of NPs. Within $60 \mathrm{~min}, 2.5 \mathrm{mM}$ of $\mathrm{H}_{2} \mathrm{O}_{2}$ was almost completely decomposed by $250 \mu \mathrm{M}$ of Fuco- $\mathrm{MnO}_{2}-\mathrm{NPs}$ (Figure 1e). Then, the generation of $\mathrm{O}_{2}$ at a low concentration of $\mathrm{H}_{2} \mathrm{O}_{2}(250 \mu \mathrm{M})$ was evaluated under a hypoxic condition. Owing to the high activity of the Fuco- $\mathrm{MnO}_{2}-\mathrm{NPs}$, a significant amount of oxygen was detected (Figure 1f). These results indicate that fucoidan coating does not affect the reactivity of $\mathrm{MnO}_{2}-\mathrm{NPs}$ toward $\mathrm{H}_{2} \mathrm{O}_{2}$.

\subsection{Fuco-MnO $\mathrm{O}_{2}-\mathrm{NPs}$ Radiosensitized Pancreatic Cancer Cells in Vitro}

To determine the optimal nanoparticle dosage, the cytotoxicity of Fuco- $\mathrm{MnO}_{2}-\mathrm{NPs}$ was assessed in human pancreatic cancer cell lines (AsPC-1 and BxPC-3) using a cell counting kit 8 (CCK-8; Dojindo, Mashiki-machi, Japan) assay (Figure 2a). Both PAH-MnO${ }_{2}-\mathrm{NPs}$ and Fuco- $\mathrm{MnO}_{2}-\mathrm{NPs}$ inhibited the cell proliferation of AsPC- 1 and BxPC-3 in a dose-dependent manner. Notably, Fuco- $\mathrm{MnO}_{2}-\mathrm{NPs}$ were slightly less toxic than $\mathrm{PAH}-\mathrm{MnO}_{2}-\mathrm{NPs}$ at $5 \mu \mathrm{g} / \mathrm{mL}$ and $10 \mu \mathrm{g} / \mathrm{mL}$, although the difference was not significant (Figure 2a). 

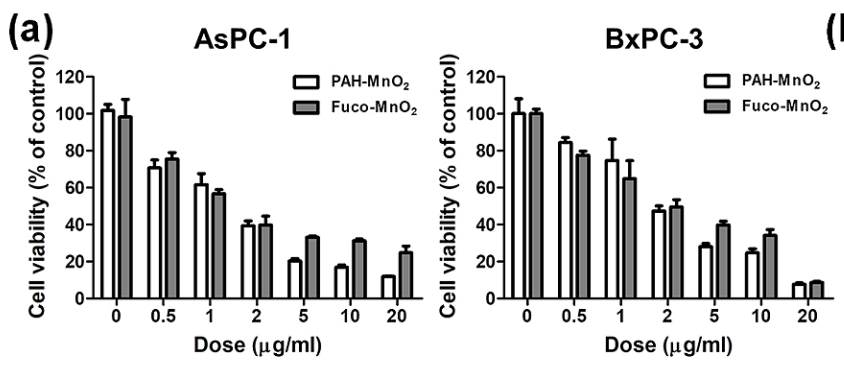

(b)

(c)

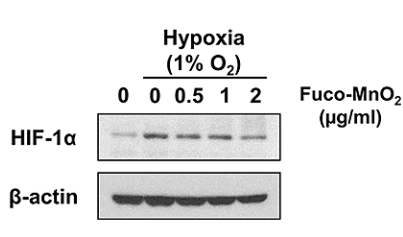

(d)

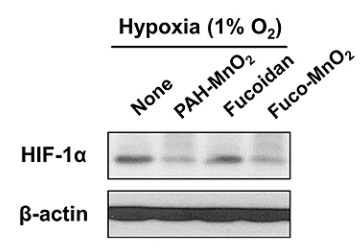

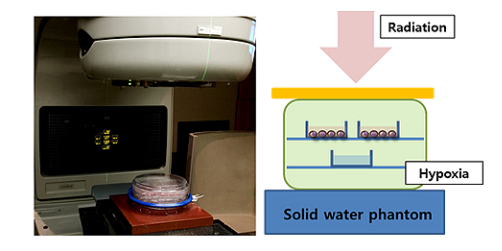

(e)

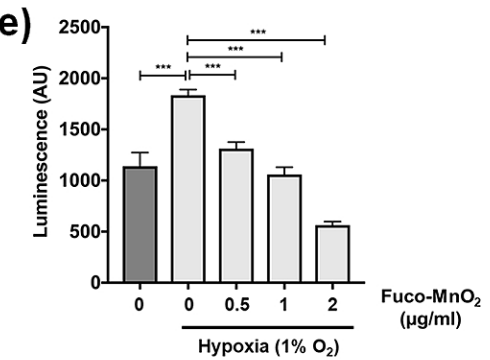

(f)
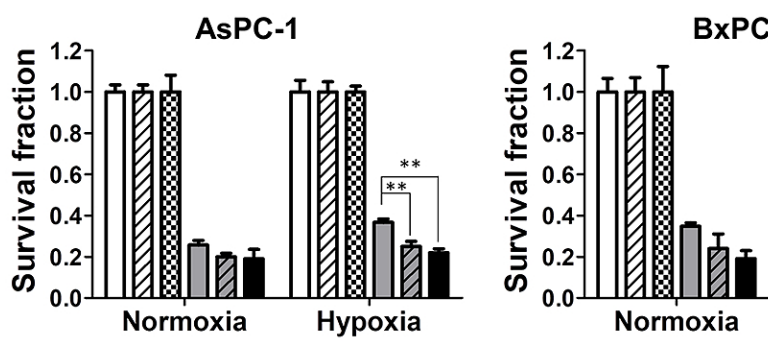

BxPC-3

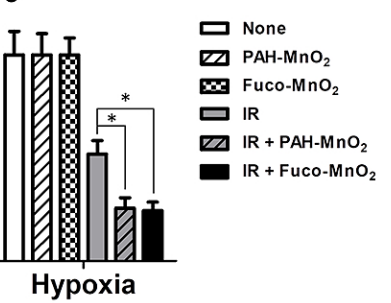

Figure 2. In vitro radiosensitizing effect of fucoidan-coated manganese dioxide nanoparticles (Fuco- $\mathrm{MnO}_{2}-\mathrm{NPs}$ ) in human pancreatic cancer cells. (a) AsPC-1 and BxPC-3 cells were cultured in complete medium and treated with different concentrations of PAH-MnO $\mathrm{M}_{2}-\mathrm{NPs}$ or Fuco-MnO${ }_{2}-\mathrm{NPs}$ $(0,0.5,1,2,5,10$ and $20 \mu \mathrm{g} / \mathrm{mL})$ for $48 \mathrm{~h}$. Cell viability was assessed using the cell counting kit 8 (CCK-8 kit). Data are presented as mean \pm standard deviation (SD) normalized to the values for an untreated control $(n=4)$. (b) Schematic view of irradiation setup. Simulated hypoxia was established by culturing human pancreatic cancer cells in a modular incubator chamber flushed with $1 \%$ oxygen. (c) Fuco- $\mathrm{MnO}_{2}$-NPs inhibited hypoxia-driven HIF-1 $\alpha$ expression in a dose-dependent manner. (d) $\mathrm{PAH}-\mathrm{MnO}_{2}-\mathrm{NPs}$ and Fuco-MnO $\mathrm{Mn}_{2}-\mathrm{NPs}$ but not fucoidan inhibited HIF- $1 \alpha$ expression under hypoxia. (e) Fuco-MnO ${ }_{2}$-NPs inhibited luciferase reporter activity driven by hypoxia-response elements $(n=3)$. (f) Radiosensitivity was determined by clonogenic survival assay. AsPC- 1 and BxPC-3 cells were pretreated with $10 \mu \mathrm{g} / \mathrm{mL}$ of either $\mathrm{PAH}-\mathrm{MnO}_{2}-\mathrm{NPs}$ or Fuco-MnO $2-\mathrm{NPs}$, followed by $4 \mathrm{~Gy}$ of X-ray irradiation. Colonies with $>50$ cells were counted. Data are presented as mean $\pm \operatorname{SD}(n=4)$; ${ }^{*} p<0.05 ; * * p<0.01$.

Next, to determine the radiosensitizing effect of Fuco- $\mathrm{MnO}_{2}-\mathrm{NPs}$ on hypoxic tumor cells, we devised a system in which hypoxic tumor cells are irradiated using a hypoxia chamber (Figure 2b). The establishment of a hypoxic tumor cell culture condition was confirmed by measuring the increased expression of HIF- $1 \alpha$ using Western blot analysis (Figure 2c), and increased luminescence using a hypoxia-responsive luciferase activity assay (Figure 2e). Treatment with Fuco- $\mathrm{MnO}_{2}-\mathrm{NPs}$ and $\mathrm{PAH}-\mathrm{MnO}_{2}-\mathrm{NPs}$, but not fucoidan alone, clearly suppressed hypoxia-induced HIF- $1 \alpha$ expression (Figure 2c,d) or hypoxia-responsive luciferase activity (Figure 2e) in pancreatic cancer cells, indicating that the Fuco- $\mathrm{MnO}_{2}-\mathrm{NPs}$ alleviated the hypoxic condition via the generation of oxygen.

The sensitization of the pancreatic cancer cells to radiation by Fuco- $\mathrm{MnO}_{2}-\mathrm{NPs}$ was assessed by a clonogenic assay using the hypoxia chamber system described above (Figure 2f). The survival of AsPC-1 and BxPC-3 cells was slightly higher after treatment with ionizing radiation (IR) of 4 Gy X-rays under the hypoxic condition than under a normoxic condition, which suggests a hypoxia-mediated radiation resistance phenotype. Fuco- $\mathrm{MnO}_{2}-\mathrm{NPs}$ and $\mathrm{PAH}-\mathrm{MnO}_{2}-\mathrm{NPs}$ decreased the clonogenic 
survival of AsPC-1 and BxPC-3 cells under hypoxic condition in response to IR (Figure 2f), indicating that these NPs resensitized radioresistant pancreatic cancer cells by relieving hypoxia.

\subsection{Fuco-MnO ${ }_{2}-\mathrm{NPs}$ Enhanced Radiation-Induced Apoptosis in a Hypoxic Condition}

We examined the effects of Fuco- $\mathrm{MnO}_{2}$-NPs on IR-mediated cell-cycle redistribution using flow cytometry (Figure 3a). A DNA content analysis with propidium iodide (PI) staining in BxPC-3 cells revealed that cell populations at sub-G1, but not other cell cycle phases, increased at 72 post-irradiation; this effect was slightly weaker in the hypoxic condition than in the normoxic condition (Figure 3a). Fuco- $\mathrm{MnO}_{2}-\mathrm{NPs}$ and $\mathrm{PAH}-\mathrm{MnO}_{2}-\mathrm{NPs}$, but not fucoidan alone, slightly increased IR-induced sub-G1 populations, even though the difference was not statistically significant. Given that the induction of the sub-G1 peak may represent DNA fragmentation during apoptosis, we determined the impact of Fuco- $\mathrm{MnO}_{2}$-NPs on IR-induced apoptosis using flow cytometry with Annexin V and PI double staining (Figure 3b). 6 Gy of IR dramatically increased the apoptotic cell population under the normoxic condition, and this effect was suppressed by hypoxic culture $(28.7 \%$ vs. $15.0 \%, p<0.005)$. The combination treatment with Fuco- $\mathrm{MnO}_{2}-\mathrm{NPs}$ and IR significantly increased the percentage of apoptotic cells compared with IR alone $(15.0 \%$ vs. $25.2 \%, p<0.05)$ under the hypoxic condition, but not under the normoxic condition.

(a)
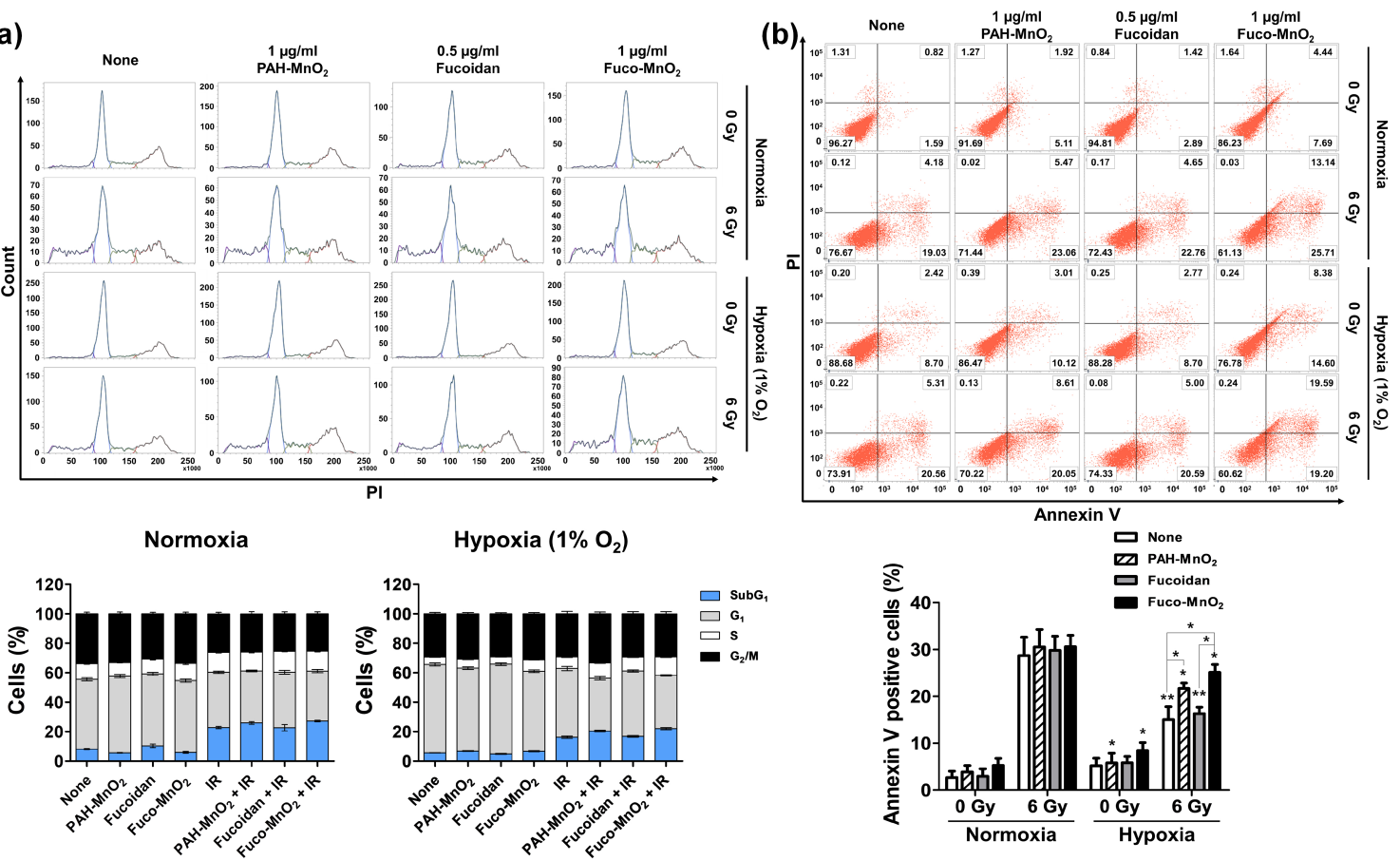

Hypoxia $\left(1 \% \mathrm{O}_{2}\right)$
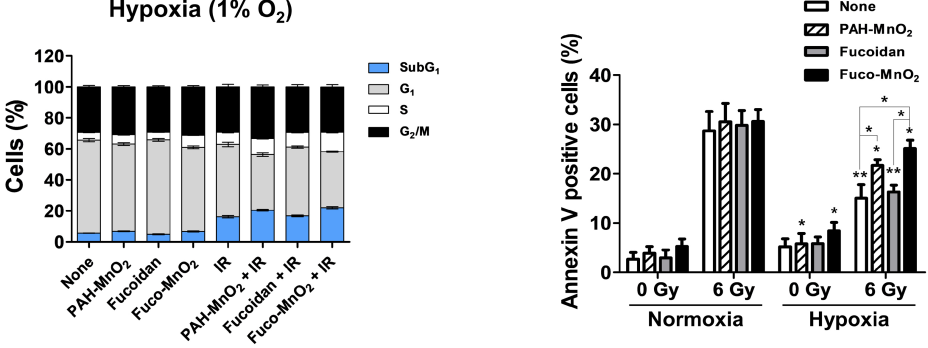

Figure 3. Effects of fucoidan-coated manganese dioxide nanoparticles (Fuco- $\mathrm{MnO}_{2}-\mathrm{NPs}$ ) on ionizing radiation (IR) -induced apoptotic cell death in BxPC-3 cells. (a) Flow cytometry evaluation of cell cycle progression at $72 \mathrm{~h}$ post-irradiation. BxPC-3 cells were pretreated with $0.5 \mu \mathrm{g} / \mathrm{mL}$ of fucoidan and $1 \mu \mathrm{g} / \mathrm{mL}$ of $\mathrm{PAH}-\mathrm{MnO}_{2}-\mathrm{NPs}$ and $\mathrm{Fuco}-\mathrm{MnO}_{2}-\mathrm{NPs}$ for $3 \mathrm{~h}$ in a hypoxic ( $1 \%$ oxygen) or normoxic condition and then exposed to IR. 6 Gy of X-ray was applied because 4 Gy was not strong enough to induce apoptosis in BxPC-3 cells. After $72 \mathrm{~h}$, cells were fixed and stained with PI. Histograms show the representative DNA content stained with PI. Stacked bar graphs show the relative percentage of cells at different cell cycle phases $(n=3)$. (b) Apoptosis was assessed by percentage of Annexin-V-positive cells using flow cytometry. PAH- $\mathrm{MnO}_{2}-\mathrm{NPs}$ and Fuco- $\mathrm{MnO}_{2}-\mathrm{NPs}$ reversed suppression of IR-induced apoptosis by hypoxia $(n=3)$. Data are presented as mean $\pm \mathrm{SD} ;{ }^{*} p<0.05 ;{ }^{* *} p<0.01$. 


\subsection{Fuco-MnO $\mathrm{O}_{2}-\mathrm{NPS}$ Inhibited DSB Repair and HIF-1 $\alpha$ Expression under Hypoxia}

To elucidate the underlying mechanisms of radiosensitization by Fuco- $\mathrm{MnO}_{2}-\mathrm{NPs}$, we determined the repair kinetics of IR-induced DNA damage. The DNA repair was evaluated by measuring the foci of phosphorylated histone $\mathrm{H} 2 \mathrm{AX}(\gamma-\mathrm{H} 2 \mathrm{AX})$, which is a sensitive indicator of DSB. $\gamma-\mathrm{H} 2 \mathrm{AX}$ foci were clearly seen within cell nuclei at $2 \mathrm{~h}$ post-irradiation, and some of the foci had disappeared at $24 \mathrm{~h}$ post-irradiation owing to the repair process (Figure $4 \mathrm{a}$, upper panel). The number of $\gamma-\mathrm{H} 2 \mathrm{AX}$ foci at $24 \mathrm{~h}$ post-irradiation was less in the hypoxia than under the normoxia condition, indicating an oxygen effect on DNA damage repair (Figure 4a, lower panel). PAH- $\mathrm{MnO}_{2}-\mathrm{NPs}$ or Fuco-MnO $2-\mathrm{NPs}$ increased the numbers of $\gamma-\mathrm{H} 2 \mathrm{AX}$ foci at $24 \mathrm{~h}$ post-irradiation compared to the saline control or fucoidan (Figure 4a, right panel). Thus, our data suggest that Fuco- $\mathrm{MnO}_{2}-\mathrm{NPs}$ may attenuate DNA damage repair through increased oxygen effect, resulting in radiosensitization in BxPC-3 cells.
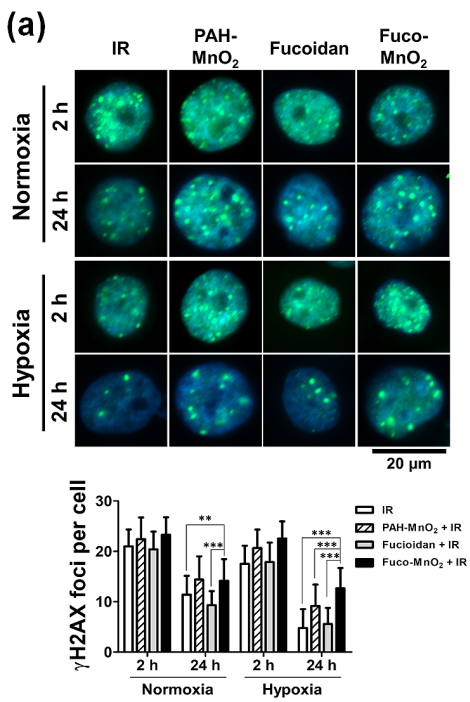

(b)

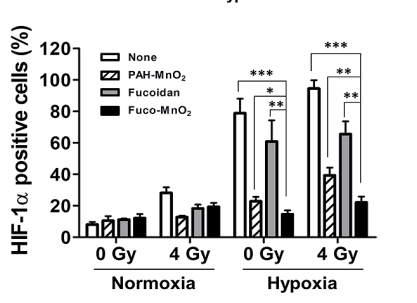

(c)
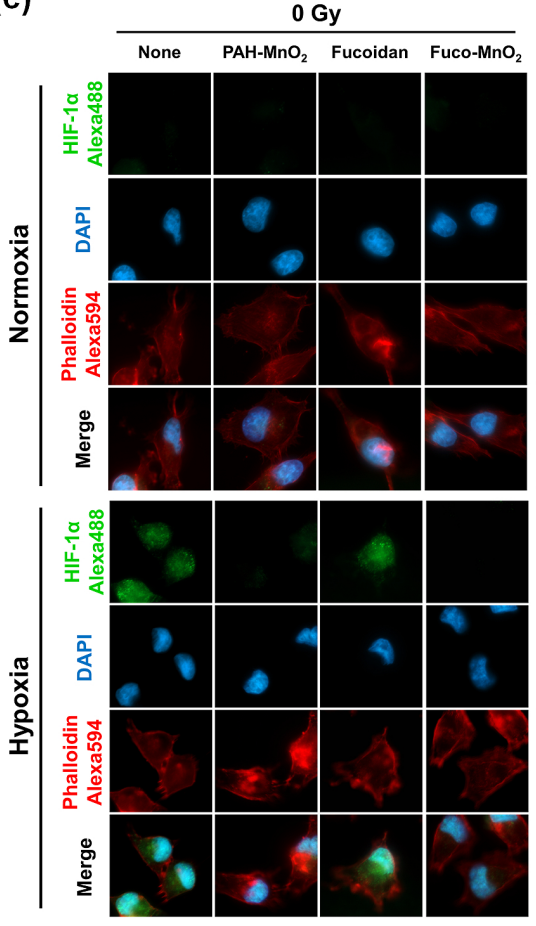
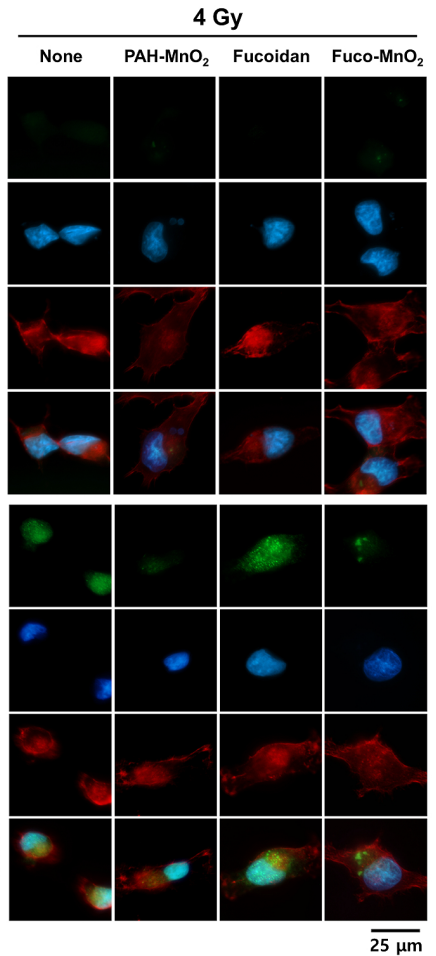

Figure 4. Effects of fucoidan-coated manganese dioxide nanoparticles Fuco- $\mathrm{MnO}_{2}-\mathrm{NPs}$ on DNA damage repair and hypoxia-inducible factor 1 (HIF-1 $\alpha$ ) expression after exposure to ionizing radiation IR. (a) Representative immunofluorescence images of $\gamma-\mathrm{H} 2 \mathrm{AX}$ foci in BxPC-3 cells at $2 \mathrm{~h}$ and $24 \mathrm{~h}$ postirradiation (upper panel). BxPC-3 cells were pretreated with fucoidan, $\mathrm{PAH}-\mathrm{MnO}_{2}-\mathrm{NPs}_{\mathrm{s}}$ and Fuco- $\mathrm{MnO}_{2}$-NPs for $3 \mathrm{~h}$, followed by 4 Gy of IR under hypoxic or normoxic conditions. The $\gamma-\mathrm{H} 2 \mathrm{AX}$ foci were seen in green, and the nuclei were counterstained with DAPI. Quantification data (lower panel) show that $\mathrm{MnO}_{2}$-NPs attenuated DNA damage repair; $n=40$. (b) Flow cytometric analysis of HIF-1 $\alpha$-positive BxPC- 3 cells. The expression of HIF- $1 \alpha$ was induced by hypoxia and was significantly decreased by $\mathrm{PAH}-\mathrm{MnO}_{2}-\mathrm{NPs}$ and Fuco- $\mathrm{MnO}_{2}-\mathrm{NPs}$. Data are presented as mean $\pm \mathrm{SD}(n=3) ;{ }^{*} p<0.05$; ** $p<0.01$. (c) Nuclear expression of HIF- $1 \alpha$ detected by immunofluorescence at $24 \mathrm{~h}$ post-irradiation. Representative images are shown. DAPI in blue; F-actin in red; HIF-1 $\alpha$ in green.

HIF- $1 \alpha$ is a key mediator of hypoxia signaling [20,21] and is involved in hypoxia-induced radioresistance. We examined the effect of Fuco- $\mathrm{MnO}_{2}-\mathrm{NPs}$ on HIF- $1 \alpha$ expression by flow cytometry and immunofluorescence imaging. The BxPC-3 cells were preincubated with $\mathrm{PAH}-\mathrm{MnO}_{2}-\mathrm{NPs}$ or Fuco- $\mathrm{MnO}_{2}$-NPs in a normoxic or hypoxic condition for $4 \mathrm{~h}$, followed by $4 \mathrm{~Gy}$ of IR. The expression of HIF- $1 \alpha$ was determined at $24 \mathrm{~h}$ post-irradiation. HIF- $1 \alpha$ expression was induced by IR alone, 
although to a much smaller degree than by hypoxia. Hypoxia markedly increased the percentage of HIF- $1 \alpha$-positive cells (Figure $4 b$ ) and the nuclear expression of HIF- $1 \alpha$ (Figure $4 \mathrm{c}$ ) in comparison with normoxia. Both $\mathrm{PAH}-\mathrm{MnO}_{2}-\mathrm{NPs}$ and Fuco- $\mathrm{MnO}_{2}-\mathrm{NPs}$ significantly suppressed hypoxia-induced HIF- $1 \alpha$ expression in BxPC-3 cells (Figure $4 b, c$ ), suggesting that $\mathrm{MnO}_{2}-\mathrm{NPs}$ may reduce radioresistance by suppressing hypoxia-induced HIF- $1 \alpha$ signaling. HIF1-1 $\alpha$ expression also decreased, but to a much lesser extent than did $\mathrm{MnO}_{2}$-NPs.

\subsection{Fuco-MnO${ }_{2}-\mathrm{NPs}$ Radiosensitized Pancreatic Cancer Cells In Vivo}

The in vivo radiosensitization effect of Fuco- $\mathrm{MnO}_{2}-\mathrm{NPs}$ in pancreatic cancer was confirmed using BxPC-3 xenograft tumor models. The effects of IR and its combination with Fuco- $\mathrm{MnO}_{2}-\mathrm{NPs}$ on tumor growth were evaluated using BALB/c nude mice bearing BxPC3 xenograft tumors. Intratumoral injection with Fuco- $\mathrm{MnO}_{2}$-NPs did not change BxPC-3 tumor growth, whereas a single 8 Gy dose of IR significantly inhibited tumor growth (Figure $5 \mathrm{a}, \mathrm{b}$ ). The combination of Fuco- $\mathrm{MnO}_{2}-\mathrm{NPs}$ and IR further delayed tumor growth compared with IR alone (Figure $5 \mathrm{a}, \mathrm{b}$ ). On day 30 , the average tumor volume in the co-treated group was reduced by $46.4 \%$ in comparison with the control group and further reduced by $22.5 \%$ compared with the IR-alone group (Figure $5 b ; p<0.05$ ). Fucoidan alone did not change tumor growth, but Fuco- $\mathrm{MnO}_{2}-\mathrm{NPs}$ did, although not in a statistically significant manner (data not shown). Unusual symptoms, such as sickness or body weight loss in mice, were not seen after injection of Fuco-MnO $2-\mathrm{NPs}$, IR at 8 Gy or their combination (Figure 5c).

(a)
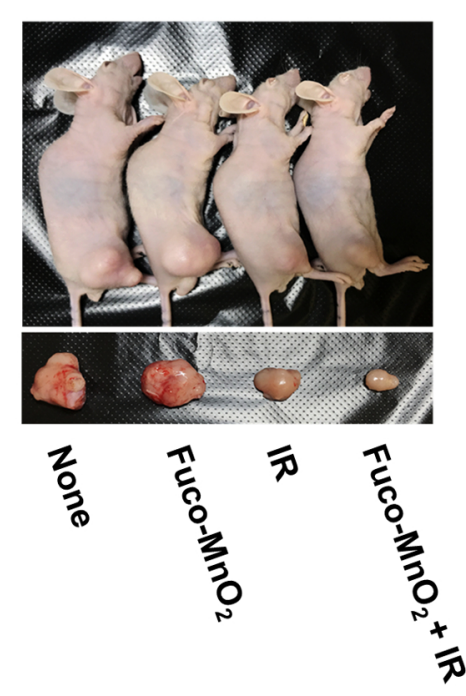

(b)

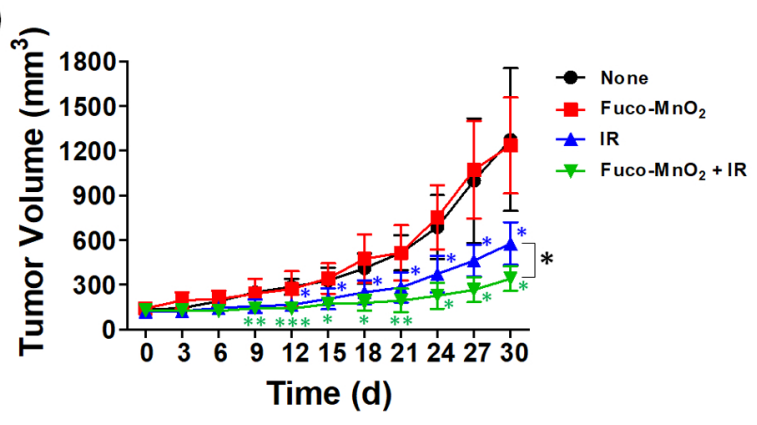

(c)

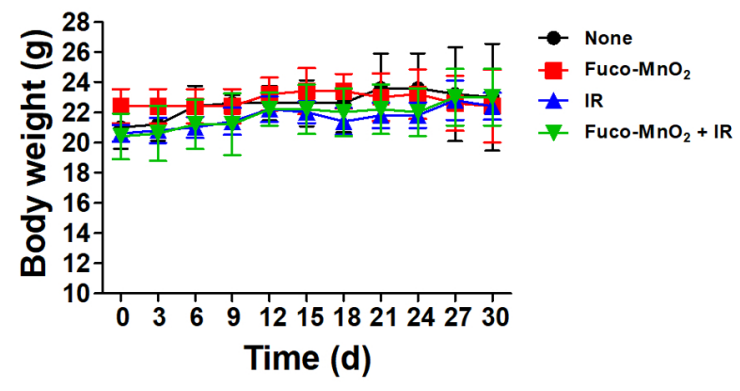

Figure 5. In vivo radiosensitizing efficacy of fucoidan-coated manganese dioxide nanoparticles (Fuco-MnO $2-\mathrm{NPs}$ ). (a) Pictures of tumors collected from BxPC-3 tumor-bearing BALB/c nude mice. On Day 30, the mice were sacrificed. (b) Fuco- $\mathrm{MnO}_{2}-\mathrm{NPs}$ did not affect BxPC-3 tumor growth. Ionizing radiation (IR) significantly reduced tumor growth, which was further inhibited by co-treatment with Fuco- $\mathrm{MnO}_{2}-\mathrm{NPs}$. The BxPC-3 cells were implanted into the right legs of BALB/c nude mice. When tumors were palpable $\left(80-150 \mathrm{~mm}^{3}\right)$, three groups of mice $(n=5$ in a group) received either Fuco- $\mathrm{MnO}_{2}$-NPs (200 ng/50 $\mu \mathrm{L}$ /week, intratumoral injection), 8 Gy of IR, or the combination of Fuco- $\mathrm{MnO}_{2}-\mathrm{NPs}$ and IR. Tumor volume was calculated as detailed in the Materials and Methods section. Data are presented as mean $\pm \mathrm{SD}$; $p<0.05$; ${ }^{* *} p<0.01 ;{ }^{* * *} p<0.001$. (c) Changes in body weight of the four groups were monitored. 


\subsection{Fuco-MnO $\mathrm{O}_{2}-\mathrm{NPs}$ Induced Apoptosis and Inhibited Angiogenesis in Irradiated BxPC-3 Xenograft Tumors}

Based on our in vitro results of the enhancement of IR-induced apoptosis by Fuco- $\mathrm{MnO}_{2}-\mathrm{NPs}$, we determined the effects of Fuco- $\mathrm{MnO}_{2}-\mathrm{NPs}$ on apoptosis in BxPC-3 xenograft tumor tissues. For this, we performed terminal deoxynucleotidyl transferase dUTP nick end-labeling (TUNEL) assay. TUNEL-positive cells were increased in the IR-treated groups and were further enhanced by either Fuco- $\mathrm{MnO}_{2}-\mathrm{NP}$ or PAH-MnO $2-\mathrm{NP}$ co-treatment (Figure $6 \mathrm{a}, \mathrm{b}$ ). This is consistent with in vitro annexin $\mathrm{V}$ staining data (Figure $3 b$ ). Fucoidan alone did not affect TUNEL staining results. Immunohistochemistry (IHC) analysis showed that HIF-1 $\alpha$ expression was greatly decreased in both Fuco- $\mathrm{MnO}_{2}-\mathrm{NP}$ and $\mathrm{PAH}-\mathrm{MnO}_{2}-\mathrm{NP}$ cotreated groups (Figure $6 \mathrm{a}, \mathrm{c}$ ), suggesting that $\mathrm{MnO}_{2}-\mathrm{NPs}$ may alleviate tumor hypoxia in vivo as well as in vitro.

(a)
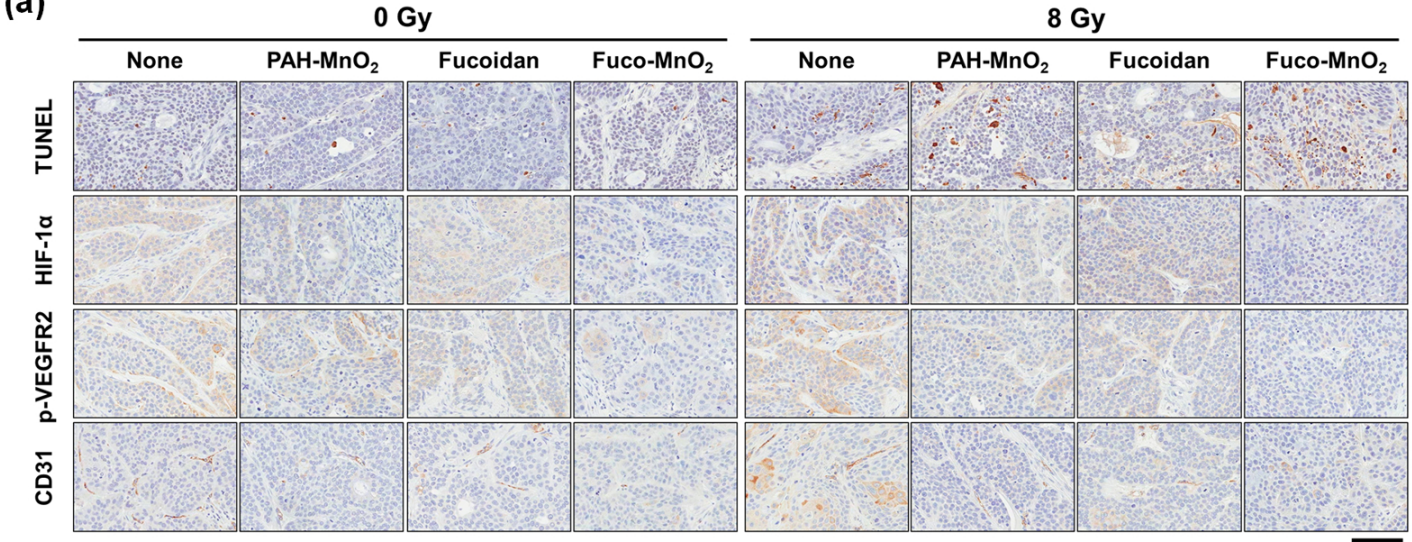

(b)

(c)

(d)
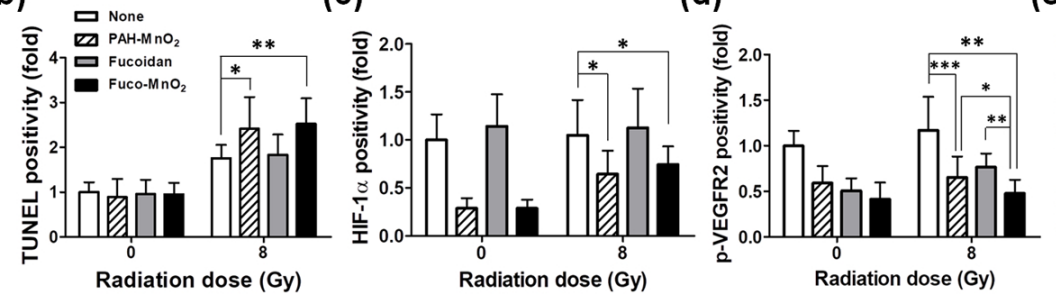

(e)

Figure 6. Effects of fucoidan-coated manganese dioxide nanoparticles (Fuco- $\mathrm{MnO}_{2}-\mathrm{NPs}$ ) on terminal deoxynucleotidyl transferase dUTP nick end-labeling (TUNEL), hypoxia-inducible-factor-1 (HIF-1 $\alpha$ ), vascular endothelial growth factor receptor 2 (phospho-VEGFR2), and cluster of differentiation 31 (CD31) expression in BxPC-3 xenograft tumor tissues. (a) Representative images of TUNEL and IHC. Tumors were harvested on Day 30 after ionizing radiation (IR) treatment. Formalin-fixed and, paraffin-embedded BxPC3 tumor tissues were further analyzed for immunohistochemistry (IHC). (b) Quantification data show that IR-induced apoptosis was further enhanced by Fuco-MnO $2-\mathrm{NPs}_{\text {, }}$ as assessed by TUNEL assays $(n=10)$, and that Fuco-MnO $-\mathrm{O}_{2}-\mathrm{NPs}$ inhibited the expression of HIF- $1 \alpha$ $(n=9)(\mathbf{c})$, phospho-VEGFR2 $(n=9)(\mathbf{d})$, and CD31 $(n=9)(\mathbf{e})$. For all graphs, data are presented as mean $\pm \mathrm{SD} ;{ }^{*} p<0.05 ;{ }^{* *} p<0.01 ;{ }^{* * *} p<0.001$.

As VEGF/VEGF receptor (VEGFR) signalling is a key factor of tumor angiogenesis and radiation resistance, we investigated the effects of Fuco- $\mathrm{MnO}_{2}$-NPs on VEGF-induced phosphorylation of VEGFR2 in BxPC-3 tumor tissue using IHC staining. Phospho-VEGFR2 expression was reduced by $\mathrm{MnO}_{2}-\mathrm{NPs}$ or fucoidan (Figure $6 \mathrm{a}, \mathrm{d}$ ). The Fuco- $\mathrm{MnO}_{2}-\mathrm{NPs}$-treated group displayed $27.0 \%$ greater reduction of phospho-VEGFR2 expression compared with the $\mathrm{MnO}_{2}-\mathrm{NPs}$-treated group. We further examined tumor vasculature with cluster of differentiation 31 (CD31) IHC staining. The expression of $\mathrm{CD} 31$, a vascular endothelial marker, showed minimal change following treatment with $\mathrm{MnO}_{2}-\mathrm{NPs}$ or fucoidan, but more marked reduction was seen in Fuco- $\mathrm{MnO}_{2}-\mathrm{NPs}$-treated tumors (Figure 6a,e). As fucoidan was previously shown to inhibit angiogenesis by downregulating HIF- $1 \alpha$ /VEGF signalling 
under hypoxia [22], it is reasonable to suggest that Fuco- $\mathrm{MnO}_{2}-\mathrm{NPs}$ were more effective at inhibiting angiogenesis than $\mathrm{PAH}-\mathrm{MnO}_{2}$-NPs.

\section{Discussion}

RT with concurrent chemotherapy is the mainstay treatment for advanced pancreatic cancer. However, high recurrence rates and resistance to previous treatment remain challenges. Several mechanisms, including tumor hypoxia, DNA damage repair, inflammation, and angiogenesis, are associated with resistance to treatment. Among these, the biological impact of oxygen on the outcome of a fractionated radiotherapy session has been widely studied. Numerous efforts to overcome hypoxia-mediated resistance to RT have only had limited success. The clinical use of hypoxia-activated prodrugs, such as evofosfamide (TH-302), has been considered as a monotherapy or in combination with various chemotherapeutics, including gemcitabine, in pancreatic cancer patients [23]. The combination effect of evofosfamide with radiation was recently studied using a pancreatic tumor orthotopic mouse model [24].

The enhancement of the therapeutic efficacy of radiotherapy in hypoxic tumors could be achieved by directly supplying adequate oxygen within tumors. Hyperbaric oxygen therapy is a well-established treatment to overcome hypoxia, where pure $\mathrm{O}_{2}$ is supplied in a pressurized room. However, this may cause overproduction of ROS in normal tissue, resulting in serious side effects such as barotrauma and hyperoxic seizures [25]. In addition, the $\mathrm{O}_{2}$ molecule can be directly delivered using its high solubility for perfluorocarbon [26]. Unfortunately, the size of perfluorocarbon-based emulsion is too large, which limits penetration into a hypoxic region. One of the strategies to deliver oxygen into hypoxic tumor tissues is to use oxygen-generating nanomaterials, such as $\mathrm{CaO}_{2}-\mathrm{NPs}$ [27], $\mathrm{C}_{3} \mathrm{~N}_{4}-\mathrm{NPs}$ [28], and catalase-containing emulsion [29]. Recent studies have reported that $\mathrm{MnO}_{2}-\mathrm{NPs}$ can convert $\mathrm{H}_{2} \mathrm{O}_{2}$, which is abundantly produced in tumor tissues, into oxygen, thus modulating tumor hypoxia and enhancing radiation efficacy in mouse models [13-15]. In these studies, $\mathrm{MnO}_{2}-\mathrm{NPs}$ are coated with biologically inactive albumin. To produce a hypoxic radiosensitizer in pancreatic cancer, we designed a new nanoplatform in which oxygen-generating $\mathrm{MnO}_{2}$-NPs were coated with bioactive marine products known as fucoidans. Fucoidans are highly sulfated cell-wall polysaccharides isolated from a species of brown seaweed. Fucoidans have diverse biological activities, including anti-inflammatory, antioxidant, and antitumor activity [16-18]. In nanomedicine, fucoidan coating is used to enhance anticancer effects and also to reduce the toxicity of metallic nanoparticles [30].

In the current study, we focused on the effects of Fuco- $\mathrm{MnO}_{2}-\mathrm{NPs}$ on RT efficacy through the modulation of a hypoxic tumor microenvironment. We first investigated the in vitro radiosensitizing activity of Fuco- $\mathrm{MnO}_{2}$-NPs against hypoxic pancreatic cancer cells. Fuco- $\mathrm{MnO}_{2}-\mathrm{NPs}$ inhibited the clonogenic survival of pancreatic cell lines, including AsPC-1 and BxPC-3, after RT under a hypoxic condition. Specifically, they enhanced radiation-induced apoptosis and attenuated DNA damage repair in BxPC-3 cells, which were suppressed by hypoxia compared with normoxia. We also obtained similar results from MIA-PaCa-2 cells (data not shown). Consistent with the in vitro data, in vivo Fuco- $\mathrm{MnO}_{2}-\mathrm{NPs}$, in combination with radiation, significantly inhibited the growth of BxPC-3 xenograft tumors. TUNEL analysis confirmed that the combination of Fuco- $\mathrm{MnO}_{2}-\mathrm{NPs}$ and radiation greatly increased apoptosis in tumor tissues. The expression of HIF- $1 \alpha$, reflecting a hypoxic microenvironment, correlates with the resistance of cells to radiation, so HIF- $1 \alpha$ is an excellent potential target for improving the efficacy of RT [31]. Fuco- $\mathrm{MnO}_{2}-\mathrm{NPs}$ additionally successfully reduced the HIF-1 $\alpha$ expression in pancreatic cancer cells cultured in a hypoxic condition, indicating efficient oxygen generation. Intratumoral injection of Fuco- $\mathrm{MnO}_{2}-\mathrm{NPs}$ also alleviated tumor hypoxia in vivo, as supported by decreased HIF- $1 \alpha$ expression in xenografted tumor tissues. These data suggest that Fuco- $\mathrm{MnO}_{2}$-NPs enhance RT efficacy via the accumulation of unrepairable DNA and induction of apoptosis, which are due to oxygenation of hypoxic tumors, as reflected by reduced HIF-1 $\alpha$ expression.

Tumor angiogenesis helps to deliver oxygen, nutrients, and growth factors to cancer cells, leading to rapid growth and metastasis [32]. HIF-1 $\alpha$ is a potent stimulator of neovascularization and excretion 
of VEGF at a transcription level, and radiation induces the upregulation of VEGF expression and angiogenesis $[33,34]$. Targeting the VEGF pathway inhibits new vessel development, causing tumor regression. Several studies have reported the potential antiangiogenic activity of fucoidans $[22,35,36]$. Fucoidan inhibits the binding of VEGF to its cell membrane receptor. The antiangiogenic properties of fucoidan were observed previously in $4 \mathrm{~T} 1$ mouse breast cancer cells both in vitro and in vivo and were related to a significant dose-dependent decrease in VEGF expression in cells treated with fucoidan [37]. However, while fucoidan did inhibit hepatoma tumor growth, it did not suppress angiogenesis or VEGF expression. This may be because the antiangiogenic effects of fucoidans depend on their diverse molecular weights and structures [38]. Our IHC data indicate that Fuco- $\mathrm{MnO}_{2}-\mathrm{NPs}$ inhibited radiation-induced angiogenesis signaling, as judged by the presence of decreased expression of phospho-VEGFR2 and CD31 in BxPC-3 xenograft tumor. The antiangiogenic activity of Fuco- $\mathrm{MnO}_{2}$-NPs may be a combination effect of $\mathrm{MnO}_{2}$-mediated HIF- $1 \alpha$ downregulation and the antiangiogenic effects of the fucoidan moiety.

Pancreatic cancer still remains a major health issue with a poor prognosis, despite the recent advance in therapeutics, and hypoxia is a major therapeutic resistance mechanism in pancreatic cancer [39]. Thus, new therapeutic strategies for overcoming hypoxia are urgently needed. The application of nanomedicine for cancer therapy has received growing attention because of many advantageous aspects, including the improvement of drug delivery to tumors. In this study, we demonstrate that Fuco- $\mathrm{MnO}_{2}-\mathrm{NPs}$ potentiated pancreatic tumors to radiation by alleviating hypoxia in vitro and in vivo. Our findings suggest the potential of this new nanoplatform that can dual-target hypoxia and angiogenesis in treating hypoxic tumors, including pancreatic cancer, to particularly improve RT efficacy.

\section{Materials and Methods}

\subsection{Materials}

$\mathrm{KMnO}_{4}$ (ACS reagent, $\geq 99.0 \%$ ), poly (allylamine hydrochloride) $(\sim 17,500 \mathrm{kDa})$ and fucoidan from Fucus vesiculosus ( $\geq 95 \%$ ) were purchased from Sigma-Aldrich (St. Louis, MO, USA). The Annexin V-FITC apoptosis detection kit was purchased from BD Biosciences (San Jose, CA, USA). Anti-rabbit and anti-mouse Alexa-Fluor-488-conjugated secondary antibodies were obtained from Molecular Probes (Carlsbad, CA, USA). Anti-HIF- $1 \alpha$ were obtained from Novus Biochemicals (Littleton, CO, USA). Antiphospho- $\gamma-\mathrm{H} 2 \mathrm{AX}$ antibodies were obtained from Cell Signaling Technology (Danvers, MA, USA) and Millipore (Burlington, MA, USA). Anti-CD31 and phospho-VEGF receptor 2 antibodies ware purchased from Abcam (Cambridge, UK). The anti- $\beta$-actin, anti-rabbit immunoglobulin $G$, and anti-mouse immunoglobulin G secondary antibodies; PI; DAPI; and fucoidan were from Sigma-Aldrich. Unless stated otherwise, all other chemicals were purchased from Sigma-Aldrich. All acronyms used in this manuscript are listed in Table A1.

\subsection{Synthesis of Nanoparticle}

$\mathrm{MnO}_{2}$-NPs were prepared according to the protocols of a previous report, with a slight modification [13]. Briefly, $18 \mathrm{~mL}$ of $\mathrm{KMnO}_{4}$ solution $(3.5 \mathrm{mg} / \mathrm{mL})$ was mixed with $2 \mathrm{~mL}$ of PAH solution $(37.4 \mathrm{mg} / \mathrm{mL})$. The mixture was vigorously stirred until the color of the solution changed to brown. $\mathrm{MnO}_{2}$-NPs coated with $\mathrm{PAH}$ were purified using a centrifugal filter (Amicon Ultra-15, MWCO $100 \mathrm{kDa}$; Millipore). The separated nanoparticles were dispersed in $15 \mathrm{~mL}$ of distilled water. The concentration of $\mathrm{Mn}^{2+}$ in the solution was determined using an inductively coupled plasma atomic emission spectrometer (ICPS-8100; Shimadzu, Kyoto, Japan). To prepare the Fuco-MnO ${ }_{2}-\mathrm{NPs}$, fucoidan was added to the $\mathrm{MnO}_{2}-\mathrm{NP}$ solution to produce a mass ratio of $\mathrm{Mn}^{2+}$ to fucoidan of 1:2, and the solution was stirred for $3 \mathrm{~h}$. The morphology of the nanoparticles was observed by TEM using an EM-2010 microscope (JEOL, Tokyo, Japan) at $200 \mathrm{kV}$. The absorption spectra of $\mathrm{KMnO}_{4}$ and $\mathrm{MnO}_{2}-\mathrm{NP}$ were obtained using a UV-Vis spectrophotometer (UV-2600; Shimidazu). The hydrodynamic size 
and zeta-potential of the nanoparticles were measured by dynamic light scattering (Zetasizer ZS90; Malvern, Worcestershire, UK).

\subsection{Measurement of $\mathrm{H}_{2} \mathrm{O}_{2}$ Decomposition and $\mathrm{O}_{2}$ Generation}

To demonstrate $\mathrm{H}_{2} \mathrm{O}_{2}$ decomposition, $2.5 \mathrm{mM}$ of $\mathrm{H}_{2} \mathrm{O}_{2}$ and $250 \mu \mathrm{M}$ of Fuco- $\mathrm{MnO}_{2}-\mathrm{NPs}$ were mixed in phosphate-buffered saline (PBS). Subsequently, $50 \mu \mathrm{L}$ of the mixture was added to $100 \mu \mathrm{L}$ of $\mathrm{Ti}\left(\mathrm{SO}_{4}\right)_{2}$ solution $\left(1.33 \mathrm{~mL}\right.$ of $24 \% \mathrm{Ti}\left(\mathrm{SO}_{4}\right)_{2}$ and $8.33 \mathrm{~mL}$ of $\mathrm{H}_{2} \mathrm{SO}_{4}$ in $50 \mathrm{~mL}$ of deionized water) every $30 \mathrm{~min}$. The concentration of $\mathrm{H}_{2} \mathrm{O}_{2}$ was estimated by measuring the absorbance at $405 \mathrm{~nm}$. To investigate the generation of oxygen, $250 \mu \mathrm{M}$ of $\mathrm{H}_{2} \mathrm{O}_{2}$ was incubated with $250 \mu \mathrm{M}$ of Fuco- $\mathrm{MnO}_{2}-\mathrm{NPs}$. Prior to the addition of Fuco- $\mathrm{MnO}_{2}-\mathrm{NPs}$, dissolved oxygen was removed by bubbling with argon. The concentration of oxygen was measured with a dissolved oxygen meter (HI9136; Hanna Instruments, Woonsocket, RI, USA).

\subsection{Cell Culture, Generation of Hypoxic Environment, and Irradiation}

AsPC-3 and BxPC-3 human pancreatic cancer cell lines were obtained from the Korean Cell Line Bank (Seoul National University, Seoul, Korea) and cultured in Roswell Park Memorial Institute 1640 medium or Dulbecco's modified Eagle's medium, supplemented with 10\% fetal bovine serum (FBS), $100 \mathrm{U} / \mathrm{mL}$ of penicillin, $100 \mu \mathrm{g} / \mathrm{mL}$ of streptomycin, and $25 \mathrm{mM}$ of HEPES (Gibco, Carlsbad, CA, USA). Cultures were maintained in a humidified atmosphere of $95 \%$ air and $5 \% \mathrm{CO}_{2}$ at $37{ }^{\circ} \mathrm{C}$.

For hypoxic cell culture, cells were placed in a Hypoxia Incubator Chamber (\#27310; STEMCELL Technologies, Vancouver, BC, Canada) that was flushed with a gas mixture of $1 \% \mathrm{O}_{2}, 5 \% \mathrm{CO}_{2}$, and $94 \% \mathrm{~N}_{2}$ (Danil Syschem, Seoul, Korea). After gas flushing, the chamber was kept in an incubator at $37^{\circ} \mathrm{C}$ in an atmosphere of $5 \% \mathrm{CO}_{2}$ prior to irradiation. Cells placed in the hypoxia chamber without gas flushing were used for the normoxic control.

For IR treatment, cell monolayers were irradiated with various doses of $6 \mathrm{MV}$ photons at a dose rate of 3.96 Gy/min using a Varian Clinac 6EX accelerator (Varian Medical Systems, Palo Alto, CA, USA).

\subsection{Cell Viability Assay}

Cell viability was measured using a CCK-8 (Dojindo, Mashiki-machi, Japan). Briefly, cells were seeded in 96-well plates at a density of $3 \times 10^{3}$ cells/well for $12 \mathrm{~h}$. After incubation with different doses of PAH-MnO ${ }_{2}$-NPs and Fuco-MnO $\mathrm{M}_{2}$-NPs for $72 \mathrm{~h}, 10 \mu \mathrm{L}$ of CCK-8 solution was added to each well and incubated for another $2 \mathrm{~h}$. The absorbance was measured at $450 \mathrm{~nm}$ using a SpectraMAX i3 microplate reader (Molecular Devices, San Jose, CA, USA).

\subsection{Clonogenic Survival Assay}

Radiosensitivity was determined by clonogenic survival assay, as previously described [40-42]. Cells were seeded in six-well plates at specific cell numbers (200-1000). The cells were pretreated with PAH-MnO ${ }_{2}$-NPs $(1 \mu \mathrm{g} / \mathrm{mL})$, fucoidan $(0.5 \mu \mathrm{g} / \mathrm{mL})$, and Fuco-MnO ${ }_{2}-\mathrm{NPs}(1 \mu \mathrm{g} / \mathrm{mL})$ for $3 \mathrm{~h}$, followed by exposure to increasing doses of IR ( $0,2,4,6$, and 8 Gy). After 7 to 14 days, cells were fixed in $98 \%$ ethanol and stained with $0.5 \%$ crystal violet (Sigma-Aldrich, St. Louis, MO, USA), and the colonies were counted using an inverted microscope (Zeiss Primovert; Carl Zeiss Co., Ltd., Jena, Germany). Colonies that contained $>50$ cells were considered viable.

\subsection{Western Blot Analysis}

Cells were harvested, washed with PBS, and treated with a lysis buffer containing $20 \mathrm{mM}$ Tris (pH 8.0), $137 \mathrm{mM}$ of $\mathrm{NaCl}, 10 \%$ glycerol, 1\% Nonidet P-40, $10 \mathrm{mM}$ EDTA, $100 \mathrm{mM} \mathrm{NaF}, 1 \mathrm{mM}$ phenylmethylsulfonyl fluoride, and $10 \mathrm{mg} / \mathrm{mL}$ leupeptin. The lysates were centrifuged at 13,000 rpm for $15 \mathrm{~min}$, and the concentration of protein in each lysate was determined using Bio-Rad protein 
assay reagent (Bio-Rad Laboratories, Hercules, CA, USA), in accordance with the manufacturer's recommendations. Then, $8 \%, 10 \%$ or $12 \%$ sodium dodecyl sulphate-polyacrylamide gel electrophoresis was used to separate $20 \mu \mathrm{g}$ protein samples. Following electrophoresis, proteins were transferred to nitrocellulose membranes (Bio-Rad Laboratories), blocked overnight in $5 \%$ skim milk in PBS at $4{ }^{\circ} \mathrm{C}$, and subsequently probed with a primary antibody. The blots were also probed with a monoclonal anti- $\beta$-actin antibody (Sigma-Aldrich, St. Louis, MO, USA) to be quantified as a relative loading control. The detection of specific proteins was carried out with enhanced chemiluminescence detection reagents (GE Healthcare, Marlborough, MA, USA) following the manufacturer's instructions.

\subsection{Cell Cycle Analysis}

In this step, $2 \times 10^{5}$ cells were plated in six-well plates and allowed to attach overnight. Then, the cells were pretreated with PAH-MnO 2 -NPs $(1 \mu \mathrm{g} / \mathrm{mL})$, fucoidan $(0.5 \mu \mathrm{g} / \mathrm{mL})$ and Fuco-MnO${ }_{2}-\mathrm{NPs}$ $(1 \mu \mathrm{g} / \mathrm{mL})$ for $3 \mathrm{~h}$ in hypoxic ( $1 \%$ oxygen) or normoxic conditions and then exposed to IR. Cell cycle analysis was performed using flow cytometry, following the staining of cells with PI after $72 \mathrm{~h}$ of incubation under hypoxic or normoxic conditions. The cells were collected by trypsinization, fixed in $70 \%$ ethanol at $-20^{\circ} \mathrm{C}$, washed in PBS, resuspended in $1 \mathrm{~mL}$ of PBS containing $1 \mathrm{mg} / \mathrm{mL}$ of ribonuclease and $50 \mu \mathrm{g} / \mathrm{mL}$ of PI, incubated in the dark for $30 \mathrm{~min}$ at $37^{\circ} \mathrm{C}$, and analyzed by flow cytometry (FACSVerse ${ }^{\mathrm{TM}}$, Becton-Dickinson, San Jose, CA, USA).

\subsection{Aapoptosis Assay}

The cells $\left(1 \times 10^{5}\right)$ were plated in six-well plates and allowed to attach overnight. The cells were exposed to hypoxic (1\% oxygen) and normoxic conditions with PAH- $-\mathrm{MnO}_{2}-\mathrm{NPs}(1 \mu \mathrm{g} / \mathrm{mL})$, fucoidan $(0.5 \mu \mathrm{g} / \mathrm{mL})$, and Fuco-MnO ${ }_{2}$-NPs $(1 \mu \mathrm{g} / \mathrm{mL})$ for $3 \mathrm{~h}$ and then exposed to IR. After $72 \mathrm{~h}$ of irradiation, the extent of apoptosis was evaluated by Annexin V-FITC and flow cytometry. Briefly, the cells were treated with trypsin, washed with PBS (pH 7.4), and stained with Annexin V-FITC (BD Biosciences, San Diego, CA, USA) and $2 \mu \mathrm{g} / \mathrm{ml}$ of PI in $100 \mu \mathrm{L}$ of Annexin V binding buffer (10 mM HEPES, $\mathrm{pH}$ $7.4 / 140 \mathrm{mM} \mathrm{NaCl} / 2.5 \mathrm{mM} \mathrm{CaCl}_{2}$ ) for $15 \mathrm{~min}$ at $37^{\circ} \mathrm{C}$ in the dark. The samples were analyzed by flow cytometry using a BD FACSVerse ${ }^{\mathrm{TM}}$ flow cytometer (BD Biosciences, San Jose, CA, USA). Data analysis was performed using the BD FACSuite ${ }^{\mathrm{TM}}$ software (BD Biosciences, San Jose, CA, USA).

\subsection{DNA Damage Repair Analysis}

DNA damage kinetics were analyzed using two approaches: flow cytometry and cell imaging of $\gamma$-H2AX immunofluorescence. For flow cytometry, $2 \times 10^{5}$ cells were plated in six-well plates and allowed to attach overnight. The cells were treated with PAH- $-\mathrm{MnO}_{2}-\mathrm{NPs}(1 \mu \mathrm{g} / \mathrm{mL})$, fucoidan $(0.5 \mu \mathrm{g} / \mathrm{mL})$, and Fuco-MnO 2 -NPs $(1 \mu \mathrm{g} / \mathrm{mL})$ for $3 \mathrm{~h}$ and subsequently exposed to IR under normoxia or hypoxia conditions. At $2 \mathrm{~h}$ or $24 \mathrm{~h}$ after irradiation, cells were collected by trypsinization and fixed in $4 \%$ formaldehyde for $10 \mathrm{~min}$, followed by permeabilization with $0.01 \%$ Triton X-100 for three min. Blocking was performed in 2\% FBS in PBS for $30 \mathrm{~min}$ at room temperature, followed by incubation for one hour at $25{ }^{\circ} \mathrm{C}$ with $\gamma$-H2AX antibody. Secondary antibodies were added and incubated for $30 \mathrm{~min}$. The samples were analyzed by flow cytometry, and data analysis was performed with BD FACSVerse ${ }^{\mathrm{TM}}$ (BD Biosciences) and BD FACSuite ${ }^{\mathrm{TM}}$ software (BD Biosciences). Negative control staining was performed with secondary antibodies alone.

For cell imaging, cells were cultured on a cover glass (Paul Marienfeld GmbH \& Co. KG, Lauda-Königshofen, Germany) and then fixed with $4 \%$ formaldehyde and permeabilized using $0.01 \%$ Triton X-100. After being blocked with $2 \%$ FBS for 30 min, cells were incubated with $\gamma-\mathrm{H} 2 \mathrm{AX}$ antibody (Millipore and Cell Signaling Technology, Danvers, MA, USA) for one hour, followed by Alexa-Fluor-488-conjugated secondary antibody (Life Technologies Corporation, Carlsbad, CA, USA) and DAPI (Sigma-Aldrich) application for $30 \mathrm{~min}$. The cells were then washed, mounted using glycerol, and analyzed by fluorescent microscopy (Zeiss Observer D1; Carl Zeiss Co., Ltd.). The nuclei were segmented and counted based on DAPI staining, while $\gamma-\mathrm{H} 2 \mathrm{AX}$ foci were counted and expressed as 
average foci per nucleus. The quantification of each independent experiment included approximately 45 cells.

\subsection{Animal Model}

All animal procedures were conducted in accordance with all appropriate regulatory standards under protocol (ID: 20160909001; approval date: 2016-09-26) approved by the Institutional Animal Care and Use Committee of Samsung Biomedical Research Institute. Six- to seven-week-old male Balb/c mice were purchased from Orient Bio (Gapyeong, Republic of Korea). BxPC-3 cells $\left(1 \times 10^{6}\right.$ cells $/ 50 \mu \mathrm{L}$ PBS) were injected subcutaneously into the right hind leg. Tumor volumes were measured every three days with calipers and calculated according to the following formula: volume $=$ DShort $^{2} \times$ DLong $\div 2$. When the mean tumor volume reached $80-150 \mathrm{~mm}^{3}$, the mice were randomized. Nanoparticles $(200 \mathrm{ng} / 50 \mu \mathrm{L})$ and fucoidan $(100 \mathrm{ng} / 50 \mu \mathrm{L})$ were administered by intratumoral injection weekly, beginning on the day of randomization. The injections were continued until the day prior to sacrifice. $4 \mathrm{~h}$ after drug treatment, the tumor was irradiated with $8 \mathrm{~Gy}$ of X-ray to the right hind leg. During irradiation, the mice were anesthetized by intraperitoneal injection of $30 \mathrm{mg} / \mathrm{kg}$ of Zoletil (Virbac, Carros, France) and $10 \mathrm{mg} / \mathrm{kg}$ of Rompun (Bayer, Leverkusen, Germany) under prescription of a veterinarian. The animals were housed under barrier conditions and fed a standard rodent diet and water. At the end of the experiment, tumor tissue was fixed with $10 \%$ neutral buffered formalin (NBF; Sigma-Aldrich, St. Louis, MO, USA) and embedded in paraffin for IHC staining.

\subsection{TUNEL Assay}

Apoptosis in the tumor tissues was determined using the TUNEL assay. The tumor tissues were fixed with $10 \% \mathrm{NBF}$ for $4 \mathrm{~h}$ and then embedded in paraffin. The slices were deparaffinized in water and placed in $3 \% \mathrm{H}_{2} \mathrm{O}_{2}$ for $10 \mathrm{~min}$ at room temperature. TUNEL staining was done using the ApopTag ${ }^{\circledR}$ Peroxidase In Situ Apoptosis Detection Kit (Millipore, Burlington, MA, USA). Images were captured using a digital pathology slide scanner (Aperio ScanScope AT; Leica Biosystems, Buffalo Grove, IL, USA). The numbers of TUNEL-positive cells were determined with the ImageScope software (Leica Biosystems, Buffalo Grove, IL, USA).

\subsection{Immunohistochemical Analysis}

Immunohistochemical studies were carried out on formalin-fixed and paraffin-embedded, $4 \mu \mathrm{m}$-thick tissue sections. Tissue sections were deparaffinized three times in xylene for a total of $15 \mathrm{~min}$ and subsequently rehydrated. Immunostaining was performed using a Bond-maxTM Polymer refines detection kit (Vision Biosystems, Melbourne, Australia). Briefly, antigen retrieval was carried out at $97^{\circ} \mathrm{C}$ for $20 \mathrm{~min}$ in an ER1 buffer. After blocking the endogenous peroxidase activity with $3 \%$ hydrogen peroxidase for $10 \mathrm{~min}$, incubation with primary antibodies was carried out for $15 \mathrm{~min}$ at room temperature at a dilution of 1:200. The primary antibodies were anti-HIF-1 $\alpha$ (Novus Biologicals, Littleton, CO, USA) and anti-phospho-VEGF receptor 2, and anti-CD31 (Abcam) was carried out for $15 \mathrm{~min}$ at room temperature at a dilution of 1:200.

\subsection{Statistical Analysis}

The significance of differences between the two groups was calculated with Student's t-tests in Microsoft Excel (Microsoft Corp., Redmond, WA, USA). The significance of differences between more than two groups was calculated with two-way analysis of variance tests in GraphPad Prism 7 (GraphPad Software, La Jolla, CA, USA). $p$ values $<0.05$ were considered statistically significant.

\section{Conclusions}

Hypoxia is a well-recognized mechanism of radioresistance, leading to tumor recurrence after RT. In this study, we demonstrated that $\mathrm{MnO}_{2}-\mathrm{NPs}$ efficiently sensitized pancreatic cancer cells to 
RT both in vitro and in vivo by alleviating hypoxia. Fucoidans, which were conjugated to NPs, exerted antiangiogenic effect in vivo. Our findings suggest a potential of the clinical use of this new nanoplatform in the treatment of hypoxic, radioresistant pancreatic cancer.

Author Contributions: C.C., N.L. and H.C.P. designed the study protocol; S.-W.S. and S.-Y.K. conducted the in vivo and histological experiments and analyzed the data; W.J. and N.L. synthetized and characterized nanomaterials; S.-W.S. and A.S. conducted in vitro experiments. S.-W.S., C.C., H.K., N.L. and H.C.P. wrote the draft of the manuscript. All authors reviewed and approved the final version of the manuscript.

Funding: This work was supported by a grant from the Marine Biotechnology Program funded by the Ministry of Oceans and Fisheries (20150220) and by a National Research Foundation of Korea (NRF) grant funded by the Korean government (MSIT) (NRF-2018R1A2B2002835).

Conflicts of Interest: The authors declare no conflict of interest.

\section{Appendix A}

Table A1. List of acronyms.

\begin{tabular}{cc}
\hline Acronyms & Description \\
\hline CD31 & Cluster of differentiation 31 \\
DAPI & $4^{\prime}$,6-diamidino-2-phenylindole \\
DSBs & Double-strand breaks \\
Fuco & Fucoidan \\
HIF-1 & Hypoxia-inducible factor 1 \\
IHC & Immunohistochemistry \\
IR & Ionizing radiation \\
NPs & Nanoparticles \\
PAH & Poly (allylamine hydrochloride) \\
ROS & Reactive oxygen species \\
RT & Radiation Therapy \\
TEM & Transmission electron microscope \\
TUNEL & Terminal deoxynucleotidyl transferase dUTP nick end-labeling \\
VEGFR & Vascular endothelial growth factor receptor \\
\hline
\end{tabular}

\section{References}

1. Siegel, R.L.; Miller, K.D.; Jemal, A. Cancer Statistics, 2018. CA Cancer J. Clin. 2018, 68, 7-30. [CrossRef] [PubMed]

2. Hidalgo, M. Pancreatic Cancer. N. Engl. J. Med. 2010, 362, 1605-1617. [CrossRef] [PubMed]

3. American Cancer Society. Cancer Facts \& Figures 2010; American Cancer Society: Atlanta, GA, USA, 2010.

4. Thota, R.; Pauff, J.M.; Berlin, J.D. Treatment of Metastatic Pancreatic Adenocarcinoma: A Review. Oncology 2014, 28, 70-74. [PubMed]

5. Conroy, T.; Desseigne, F.; Ychou, M.; Bouché, O.; Guimbaud, R.; Bécouarn, Y.; Adenis, A.; Raoul, J.L.; Gourgou-Bourgade, S.; de la Fouchardière, C.; et al. Folfirinox Versus Gemcitabine for Metastatic Pancreatic Cancer. N. Engl. J. Med. 2011, 364, 1817-1825. [CrossRef] [PubMed]

6. Ryan, D.P.; Hong, T.S.; Bardeesy, N. Pancreatic Adenocarcinoma. N. Engl. J. Med. 2014, 371, 1039-1049. [CrossRef] [PubMed]

7. Liauw, S.L.; Connell, P.P.; Weichselbaum, R.R. New Paradigms and Future Challenges in Radiation Oncology: An Update of Biological Targets and Technology. Sci. Transl. Med. 2013, 5, 173sr2. [CrossRef] [PubMed]

8. Rockwell, S.; Dobrucki, I.T.; Kim, E.Y.; Marrison, S.T.; Vu, V.T. Hypoxia and Radiation Therapy: Past History, Ongoing Research, and Future Promise. Curr. Mol. Med. 2009, 9, 442-458. [CrossRef]

9. Harada, H. How Can We Overcome Tumor Hypoxia in Radiation Therapy? J. Radiat. Res. 2011, 52, 545-556. [CrossRef]

10. Rankin, E.B.; Giaccia, A.J. Hypoxic Control of Metastasis. Science 2016, 352, 175-180. [CrossRef]

11. Moeller, B.J.; Dewhirst, M.W. HIF-1 and Tumour Radiosensitivity. Br. J. Cancer 2006, 95, 1-5. [CrossRef]

12. Horsman, M.R.; Overgaard, J. The Impact of Hypoxia and Its Modification of the Outcome of Radiotherapy. J. Radiat Res. 2016, 57 (Suppl. 1), i90-i98. [CrossRef] [PubMed] 
13. Prasad, P.; Gordijo, C.R.; Abbasi, A.Z.; Maeda, A.; Ip, A.; Rauth, A.M.; DaCosta, R.S.; Wu, X.Y. Multifunctional Albumin- $\mathrm{MnO}_{2}$ Nanoparticles Modulate Solid Tumor Microenvironment by Attenuating Hypoxia, Acidosis, Vascular Endothelial Growth Factor and Enhance Radiation Response. ACS Nano 2014, 8, 3202-3212. [CrossRef] [PubMed]

14. Abbasi, A.Z.; Gordijo, C.R.; Amini, M.A.; Maeda, A.; Rauth, A.M.; DaCosta, R.S.; Wu, X.Y. Hybrid Manganese Dioxide Nanoparticles Potentiate Radiation Therapy by Modulating Tumor Hypoxia. Cancer Res. 2016, 76, 6643-6656. [CrossRef] [PubMed]

15. Meng, L.; Cheng, Y.; Tong, X.; Gan, S.; Ding, Y.; Zhang, Y.; Wang, C.; Xu, L.; Zhu, Y.; Wu, J.; et al. Tumor Oxygenation and Hypoxia Inducible Factor-1 Functional Inhibition Via a Reactive Oxygen Species Responsive Nanoplatform for Enhancing Radiation Therapy and Abscopal Effects. ACS Nano 2018, 12, 8308-8322. [CrossRef] [PubMed]

16. Collins, K.G.; Fitzgerald, G.F.; Stanton, C.; Ross, R.P. Looking Beyond the Terrestrial: The Potential of Seaweed Derived Bioactives to Treat Non-Communicable Diseases. Mar. Drugs 2016, 14, 60. [CrossRef] [PubMed]

17. Yang, M.; Ma, C.; Sun, J.; Shao, Q.; Gao, W.; Zhang, Y.; Li, Z.; Xie, Q.; Dong, Z.; Qu, X. Fucoidan Stimulation Induces a Functional Maturation of Human Monocyte-Derived Dendritic Cells. Int. Immunopharmacol. 2008, 8, 1754-1760. [CrossRef] [PubMed]

18. Teruya, T.; Tatemoto, H.; Konishi, T.; Tako, M. Structural Characteristics and in Vitro Macrophage Activation of Acetyl Fucoidan from Cladosiphon Okamuranus. Glycoconj. J. 2009, 26, 1019-1028. [CrossRef]

19. Ye, J.; Li, Y.; Teruya, K.; Katakura, Y.; Ichikawa, A.; Eto, H.; Hosoi, M.; Hosoi, M.; Nishimoto, S.; Shirahata, S. Enzyme-Digested Fucoidan Extracts Derived from Seaweed Mozuku of Cladosiphon Novae-Caledoniae Kylin Inhibit Invasion and Angiogenesis of Tumor Cells. Cytotechnology 2005, 47, 117-126. [CrossRef]

20. Vukovic, V.; Haugland, H.K.; Nicklee, T.; Morrison, A.J.; Hedley, D.W. Hypoxia-Inducible Factor-1alpha Is an Intrinsic Marker for Hypoxia in Cervical Cancer Xenografts. Cancer Res. 2001, 61, 7394-7398.

21. Jewell, U.R.; Kvietikova, I.; Scheid, A.; Bauer, C.; Wenger, R.H.; Gassmann, M. Induction of Hif-1alpha in Response to Hypoxia Is Instantaneous. FASEB J. 2001, 15, 1312-1314. [CrossRef] [PubMed]

22. Chen, M.C.; Hsu, W.L.; Hwang, P.A.; Chou, T.C. Low Molecular Weight Fucoidan Inhibits Tumor Angiogenesis through Downregulation of HIF-1/VEGF Signaling under Hypoxia. Mar. Drugs 2015, 13, 4436-4451. [CrossRef] [PubMed]

23. Borad, M.J.; Reddy, S.G.; Bahary, N.; Uronis, H.E.; Sigal, D.; Cohn, A.L.; Schelman, W.R.; Stephenson, J., Jr.; Chiorean, E.G.; Rosen, P.J.; et al. Randomized Phase II Trial of Gemcitabine Plus Th-302 Versus Gemcitabine in Patients with Advanced Pancreatic Cancer. J. Clin. Oncol. 2015, 33, 1475-1481. [CrossRef] [PubMed]

24. Hajj, C.; Russell, J.; Hart, C.P.; Goodman, K.A.; Lowery, M.A.; Haimovitz-Friedman, A.; Deasy, J.O.; Humm, J.L. A Combination of Radiation and the Hypoxia-Activated Prodrug Evofosfamide (Th-302) Is Efficacious against a Human Orthotopic Pancreatic Tumor Model. Transl. Oncol. 2017, 10, 760-765. [CrossRef] [PubMed]

25. Chen, Q.; Huang, Z.; Chen, H.; Shapiro, H.; Beckers, J.; Hetzel, F.W. Improvement of Tumor Response by Manipulation of Tumor Oxygenation During Photodynamic Therapy. Photochem. Photobiol. 2002, 76, 197-203. [CrossRef]

26. Song, X.; Feng, L.; Liang, C.; Yang, K.; Liu, Z. Ultrasound Triggered Tumor Oxygenation with Oxygen-Shuttle Nanoperfluorocarbon to Overcome Hypoxia-Associated Resistance in Cancer Therapies. Nano Lett. 2016, 16, 6145-6153. [CrossRef] [PubMed]

27. Huang, C.C.; Chia, W.T.; Chung, M.F.; Lin, K.J.; Hsiao, C.W.; Jin, C.; Lim, W.H.; Chen, C.C.; Sung, H. An Implantable Depot That Can Generate Oxygen in Situ for Overcoming Hypoxia-Induced Resistance to Anticancer Drugs in Chemotherapy. J. Am. Chem. Soc. 2016, 138, 5222-5225. [CrossRef]

28. Zheng, D.W.; Li, B.; Li, C.X.; Fan, J.X.; Lei, Q.; Li, C.; Xu, Z.; Zhang, X.Z. Carbon-Dot-Decorated Carbon Nitride Nanoparticles for Enhanced Photodynamic Therapy against Hypoxic Tumor via Water Splitting. ACS Nano 2016, 10, 8715-8722. [CrossRef]

29. Chen, H.; Tian, J.; He, W.; Guo, Z. $\mathrm{H}_{2} \mathrm{O}_{2}$-Activatable and $\mathrm{O}_{2}$-Evolving Nanoparticles for Highly Efficient and Selective Photodynamic Therapy against Hypoxic Tumor Cells. J. Am. Chem. Soc. 2015, 137, 1539-1547. [CrossRef] 
30. Manivasagan, P.; Bharathiraja, S.; Bui, N.Q.; Jang, B.; Oh, Y.O.; Lim, I.G.; Oh, J. Doxorubicin-Loaded Fucoidan Capped Gold Nanoparticles for Drug Delivery and Photoacoustic Imaging. Int. J. Biol. Macromol. 2016, 91, 578-588. [CrossRef]

31. Moeller, B.J.; Dreher, M.R.; Rabbani, Z.N.; Schroeder, T.; Cao, Y.; Li, C.Y.; Dewhirst, M.W. Pleiotropic Effects of Hif-1 Blockade on Tumor Radiosensitivity. Cancer Cell 2005, 8, 99-110. [CrossRef]

32. Chung, A.S.; Lee, J.; Ferrara, N. Targeting the Tumour Vasculature: Insights from Physiological Angiogenesis. Nat. Rev. Cancer 2010, 10, 505-514. [CrossRef] [PubMed]

33. Park, J.S.; Qiao, L.; Su, Z.Z.; Hinman, D.; Willoughby, K.; McKinstry, R.; Yacoub, A.; Duigou, G.J.; Young, C.S.; Grant, S.; et al. Ionizing Radiation Modulates Vascular Endothelial Growth Factor (VEGF) Expression through Multiple Mitogen Activated Protein Kinase Dependent Pathways. Oncogene 2001, 20, 3266-3280. [CrossRef] [PubMed]

34. Karamanolis, G.; Delladetsima, I.; Kouloulias, V.; Papaxoinis, K.; Panayiotides, I.; Haldeopoulos, D.; Triantafyllou, K.; Kelekis, N.; Ladas, S.D. Increased Expression of VEGF and CD31 in Postradiation Rectal Tissue: Implications for Radiation Proctitis. Mediators Inflamm. 2013, 2013, 515048. [CrossRef] [PubMed]

35. Fitton, J.H.; Stringer, D.N.; Karpiniec, S.S. Therapies from Fucoidan: An Update. Mar. Drugs 2015, 13, 5920-5946. [CrossRef] [PubMed]

36. Atashrazm, F.; Lowenthal, R.M.; Woods, G.M.; Holloway, A.F.; Dickinson, J.L. Fucoidan and Cancer: A Multifunctional Molecule with Anti-Tumor Potential. Mar. Drugs 2015, 13, 2327-2346. [CrossRef] [PubMed]

37. Xue, M.; Ge, Y.; Zhang, J.; Wang, Q.; Hou, L.; Liu, Y.; Sun, L.; Li, Q. Anticancer Properties and Mechanisms of Fucoidan on Mouse Breast Cancer in Vitro and in Vivo. PLoS ONE 2012, 7, e43483. [CrossRef]

38. Zhu, C.; Cao, R.; Zhang, S.X.; Man, Y.N.; Wu, X.Z. Fucoidan Inhibits the Growth of Hepatocellular Carcinoma Independent of Angiogenesis. Evid. Based Complement. Altern. Med. 2013, 2013, 692549. [CrossRef]

39. Chand, S.; O'Hayer, K.; Blanco, F.F.; Winter, J.M.; Brody, J.R. The Landscape of Pancreatic Cancer Therapeutic Resistance Mechanisms. Int. J. Biol. Sci. 2016, 12, 273-282. [CrossRef]

40. Shin, S.W.; Choi, C.; Lee, G.H.; Son, A.; Kim, S.H.; Park, H.C.; Batinic-Haberle, I.; Park, W. Mechanism of the Antitumor and Radiosensitizing Effects of a Manganese Porphyrin, MnHex-2-PyP. Antioxid. Redox Signal. 2017, 27, 1067-1082. [CrossRef]

41. Yu, J.I.; Choi, C.; Shin, S.W.; Son, A.; Lee, G.H.; Kim, S.Y.; Park, H.C. Publisher Correction: Valproic Acid Sensitizes Hepatocellular Carcinoma Cells to Proton Therapy by Suppressing Nrf2 Activation. Sci. Rep. 2018, 8, 7597. [CrossRef]

42. Choi, C.; Son, A.; Lee, H.S.; Lee, Y.J.; Park, H.C. Radiosensitization by Marine Sponge Agelas Sp. Extracts in Hepatocellular Carcinoma Cells with Autophagy Induction. Sci. Rep. 2018, 8, 6317. [CrossRef] [PubMed] 